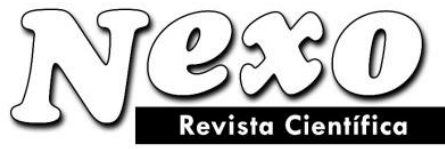

ISSN-E 1995-9516

Universidad Nacional de Ingeniería COPYRIGHT @ (UNI). TODOS LOS DERECHOS RESERVADOS http://revistas.uni.edu.ni/index.php/Nexo https://doi.org/10.5377/nexo.v34i02.11628

Vol. 31, No. 02, pp. 1032-1038/Junio 2021

(c) (i) $($ )

\title{
City with Smart Waste Management: Introducing Waste Bin Technologies
}

\section{Ciudad con Gestión Inteligente de Residuos: Introducción de Tecnologías de contenedores de desechos}

\author{
Arya Majidi \\ Department of Information Technology, Mehr Alborz University, Tehran, Iran \\ Arya50009@yahoo.com
}

(recibido/received: 02-febrero-2021; aceptado/accepted: 14-abril-2021)

\begin{abstract}
Population growth and urbanization have led to an increase in the rate of waste production, the lack of timely and proper management of which will have adverse effects on human life and the environment. Since most of the waste management costs are spent on waste collection and transportation, it is necessary to find solutions to control the huge costs of this sector. On the other hand, today, intelligent technologies are used globally as solutions to meet challenges in various fields such as agriculture to improve agro-industrial production, transportation, and waste management, which creates a concept called smart cities. One of the categories that has changed the concept of cities and made them have easier and smarter answers to various events and needs is the "Internet of Things", in which many cases and infrastructures with new hardware technologies and Software are integrated. Waste collection is no exception to this rule and efforts have been made to make it smarter. In this research, some of the latest innovations presented globally in order to make trash smarter have been examined.
\end{abstract}

Keywords: Internet of Things (IoT), Waste collection, Smart trash, Radio frequency identification, Smart waste management

\section{RESUMEN}

El crecimiento de la población y la urbanización han provocado un aumento en la tasa de producción de residuos, cuya falta de gestión oportuna y adecuada tendrá efectos adversos sobre la vida humana y el medio ambiente. Dado que la mayoría de los costes de gestión de residuos se gastan en la recogida y el transporte de residuos, es necesario encontrar soluciones para controlar los enormes costes de este sector. Por otro lado, hoy en día, las tecnologías inteligentes se 
utilizan a ni el mundial como soluciones para enfrentar desafíos en diversos campos como la agricultura para mejorar la producción agroindustrial, el transporte y la gestión de residuos, lo que crea un concepto llamado ciudades inteligentes. Una de las categorías que ha cambiado el concepto de ciudades y las ha hecho tener respuestas más fáciles e inteligentes a diversos eventos y necesidades es el "Internet de las cosas", en el que se integran muchos casos e infraestructuras con nuevas tecnologías hardware y Software. La recolección de residuos no es una excepción a esta regla y se han hecho esfuerzos para hacerla más inteligente. En esta investigación, se han examinado algunas de las últimas innovaciones presentadas a nivel mundial para hacer que la basura sea más inteligente.

Palabras clave: Internet de las cosas (IoT), Colecta de residuos, Basura inteligente, Identificación por radiofrecuencia, Gestión inteligente de residuos.

\section{INTRODUCTION}

Many scientists like Aleyadeh et al., (2018) have discussed the potential of various communication and information technologies such as radio frequency identification, GIS, and various transportation models to monitor trash and collect garbage. Real things have been done that have limitations. In other research, Mamun, et al (2013) collect information about the status of trash in real time through a GSM /GPRS bin to server connection, which requires a plan with a GSM /GPRS connection in each bin, which greatly increases operating costs. The use of pervasive computing technology such as RFID and sensor networks opens up a new way to optimize waste management systems. Bharadwaj et al. (2016) believes adoption of RFID technology has increased in many areas of application such as logistics, inventory, public transportation and security. Basically RFID allows digital information from one or more objects to be read using a near-object reader, and is able to examine features, track, auto-identify, and more. RFID is expected to replace barcodes and be connected to most goods by manufacturers and / or retailers. So, RFID is an important opportunity for waste management because RFID tags can be used to improve current waste management processes. Chuah (2014) believes Internet of Things (IoT) will expand the concept of cities 9(and enable them to more easily provide intelligent responses to a variety of events and needs, as well as integrate anything and infrastructure with new hardware and software technologies. The Internet of Things is a concept in which the surrounding objects are connected to the Internet via wired and wireless networks without user intervention. In the field of IoT, objects perform communication and information exchange can provide advanced intelligent services to users. The developments in the Internet, with its underlying technologies, smart sensors and communication technologies, supply the probability of relating machines, devices, software, and objects communicating among them without human intervention. Therefore, creating the way for a new concept named the Internet of Things (IoT). The main definitions of IoT is that IoT is a dynamic and worldwide network organization, where intelligent things, subsystems and individual physical and virtual qualities are recognizable, autonomous, and self-configurable. Various investigations have been dedicated to IoT technologies, such as Radio-Frequency Identification (RFID) technologies, sensors and actuators, wireless mobile. These advances permit IoT technologies to bridge the gap between present network-based devices and technologies that monitor and collect data from physical world observations and supply new services and applications employed to enhance the living situations of people in many regions (Lundin AC, Et al, 2017). Therefore, the IoT can deliver important savings, enhancing using of a city's assets, increase process performance, and add 
productivity by connecting low-cost technologies directly. Some examples of these applications are smart cities, homes and offices, logistics and distribution systems, healthcare, surveillance and security, the supply chain, manufacturing industry, etc. In smart cities, the efficient management of waste is a crucial challenge for the environment that IoT tends to address. Due to recent advances in mobile devices equipped with various sensors and communication modules, IoT technology has received a great deal of academic attention (Lundin, et al, 2017). The term IoT was introduced by Kevin Ashton, director of the MIT Auto-ID Center in 1999. The Internet of Things (IoT) was first achieved by using RFID technology to identify and track devices and store device information technically. IoT technology, however, is limited to tracking and extracting specific object information using RFID (Labib, 2017). At present, IoT performs measurement, data collection, storage, and processing by connecting physical or virtual devices to the Internet (Mustafa, et al.,2017). A variety of IoT research services have been conducted, including environmental monitoring, object tracking, traffic management, healthcare, and smart home technology (Muyunda, et a., 2017). Given the features and benefits of IoT services, waste management has also become an important issue in academia, industry and government as major areas of IoT application (Papalambro, et al., 2015).

\section{LITERATURE REVIEW}

Many projects have conducted on waste management and reported in literatures. In research carried out by Saha et al., a concept of intelligent disposal Saha et al. It brings a concept of intelligent disposal through a plan that consumes solar energy to feed the system and presence sensors for monitoring the amount of waste aggregated inside the enclosure. Catania et al. (2014) believes the data about the fill level is sent through wireless relationship to a cloud server where it is stored. The smart bin can perform as a Wi-Fi hotspot, and it is easily adapted to any kind of container, from small containers to big garbage containers (Pardini, et al, 2018). In turn, concessionaires access the system through a login and have access to data analysis, allowing fill level monitoring of smart bins, in real time, with notifications of need for collection through information that including optimized path for waste collection. Folianto et al.(2015) believes this intelligent solution aids utilities decrease truck fleet, decrease fuel usage, and magnifying pick up time, minimizing operating expenses by up to $80 \%$ (Pardini et al., 2018). Based on a study in Denmark, an intelligent waste management system consisting of wireless nodes with ultrasonic sensors to measure empty space in bins, a sensor input based on a long-range broadband protocol, and cloud-based back/front end to collect, analysis and visualization of data were formed and studied in an experimental study (Sharma, et al,2015). In accordingly, 6 bins in the open air were monitored remotely. The results showed that existing technologies were sufficiently developed to be able to install inexpensive additive sensors on the bins outlet (Shyam, et al., 2017). Other studies from Guerrero et al (2013) show that using such a system could provide the necessary insight to optimize waste collection processes, to prevent garbage bins from overflowing, and to enhance the citizens' experience. Another research from Glouche et al (2013) conducted in Italy presented an approach to intelligent monitoring and planning of municipal waste management using M3 intelligent software platforms. In this work, waste collection was carried out by real-time monitoring of the fullness of the trash through sensors placed inside the containers. In addition, input data could be provided to decision algorithms to determine the optimal number of waste transport vehicles or the distribution of waste bins on the 
ground. The presented solution in this study had two main phases: 1) monitoring phase in which the fullness of the bins was continuously measured and 2) a computational phase in which the collected data were collected to optimize waste collection. The proposed solution had significant advantages both for service providers due to reasonable cost reductions and for consumers due to better service quality. In order to create a closer feeling between users and the community, they could interact with the system to find the nearest buckets. Finally, a collection mechanism called "green dots" was introduced to encourage citizens to recycle process.

In a research project conducted by Indian researchers to make trash smart, each smart trash was equipped with ultrasonic sensors that measured the filling level of the trash. Each container was divided into three levels of waste collected inside. With constant use, those levels gradually filled over time. Each time the garbage passed a level, the sensors received the filled level data. This data was then sent to the waste analyzer in the form of an instant message using the GSM module. Each received message was stored as data by the analyzer and later used for predictive processing, analysis and modeling. Real-time data received was used by the software interface to better view the filled level. The received data was stored in the database while retaining all the intact features of time and date. Records of data collected over the months were used by the data analysis department for forecasting and reporting. Another research by Hong et al., (2014) show the software interface showed the real-time level to the waste analyzer, and using it, he sent his waste collection team to collect the waste before it overflowed. The forecast model was designed to predict when each level of the container will be filled in the future. This helped the Department of Waste Management optimize the route for garbage collection whenever the garbage collector in the city moved to collect garbage. This action saves the organization's time and resources were wasted, and then the work was done more efficiently. Shyam et al, presented an intelligent collection system based on the amount of residues existed in the compartments and updated data on landfills. The system contains sensors located in a compartment that characterize the level of residues present internally via the distance evaluated from the cover and the beginning of the deposited garbage (Jain et al., 2017). For this purpose, they employ a sonar device such as HC-SR04. A battery-optimization process has been considered, which can be obtained through optimized waste detection rates in connection with a wireless transmission system. This is a factor with strong impact on energy usage that can enhance the life of the device.

\section{GENERAL PROPOSAL}

In this article, the design and mechanism discussed is aimed to solve the problems of collecting and separating solid waste (which usually contains low carbon) due to the existence of intelligent mechanisms of air conditioning and piping to pump waste water, has a significant capacity to accept waste. A smart landfill is a structure that creates a space of $250 * 200 * 600$ dimensions below the ground (figure 1), which includes waste collection tanks in various materials, designs and shapes. These tanks have the ability to store up to 4000 liters of waste. Intelligent control chamber is designed for the device that controls all waste mechanisms. Also for this control room, a remote system is designed to establish a human agent connection to order the system. Mobile frame that can move garbage cans to the ground and is placed on the lift. Tank weight- 
sensitive weighing system that sends tank capacity information to the control room and, as a result, notifies the human operator when the tanks are being evacuated.

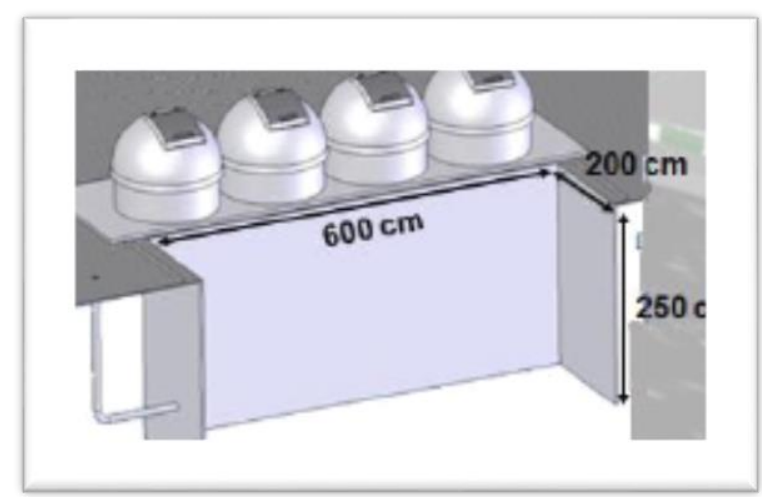

Figure 1: The structure and space of the smart bin

The upper part that is located on the ground and at the waste inlet, designed restrictions is implemented to receive the desired dry waste on each tank. This section is equipped with multimedia advertising monitors and broadcasts advertisements that will target the investment of municipalities. The landfill is equipped with an intelligent air conditioning system, and as soon as the percentage of waste gases exceeds the standard level, the system will automatically activate the air conditioning system, and as a result, the amount of gases in the tanks will be reduced. On the other hand, the device is equipped with a fire extinguishing system to deal with possible fires.

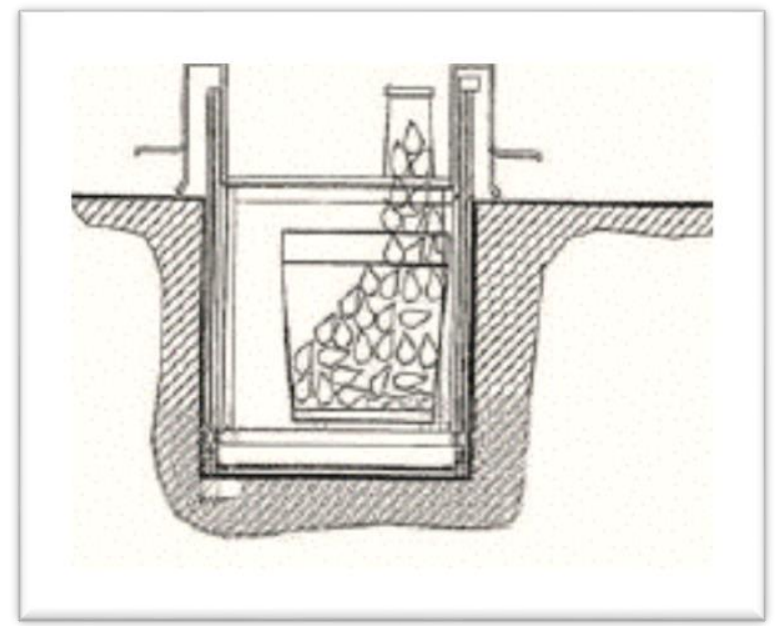

Figure 2: An overview of waste collection 


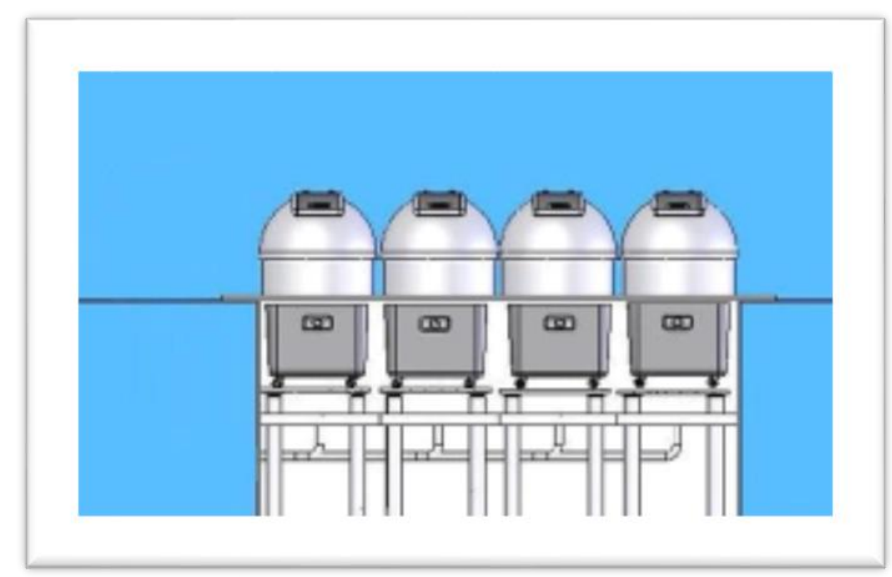

Figure 3: Overview of the smart bin

\section{CONCLUSION}

Irregular waste generation and inefficient waste management policies, such as the lack of waste segregation programs, have led to serious environmental problems and huge waste collection costs. To address these problems, various researches have been conducted worldwide for waste management in the collection sector based on IoT technology. Considering the problems and costs related to waste collection in the country and considering the successful experiences of different countries in smartening different parts of the collection system, this study pays attention to smartening the various elements of the waste management system as a way to help Recommending the adoption of intelligent technologies to solve problems in the field of waste management to the authorities.

Conflicts of Interest: The authors declare no conflict of interest.

\section{REFERENCES}

Aleyadeh, S, Taha, A.M. (2018).“An IoT-Based Architecture for Waste Management. In Proceedings". "IEEE International Conference on Communications Workshops". Kansas City, MO, USA.

Al Mamun MA, Hannan MA, Hussain A, Basri H. (2013). "Wireless sensor network prototype for solid waste bin monitoring with energy efficient sensing algorithm".Computational Science and Engineering, IEEE.

Bharadwaj, A.S.; Rego, R.; Chowdhury,A.(2016). "IoT based solid waste management system: A conceptual approach with an architectural solution as a smart city application". Proceedings of the IEEE Annual India Conference, Bangalore, India.

Chuah, J.W. (2014).'The Internet of Things: An overview and new perspectives in systems design". Proceedings of the IEEE Conferences, International Symposium on Integrated Circuits, Singapore.

Catania V, Ventura D. (2014). "An approach for monitoring and smart planning of urban solid waste management using smart-M3 platform". Open Innovations Association FRUCT, Proceedings of 15th Conference, IEEE. 
Folianto, F.; Sheng, Y. Low Smartbin(2015), “SmartWaste Management System'. Proceedings of the IEEE Tenth International Conference on Intelligent Sensors, Sensor Networks and Information Processing, Singapore.

Guerrero LA, Maas G, Hogland W.(2013)." Solid waste management challenges for cities in developing countries". Waste Managemen journal.

Glouche Y, Couderc P. (2013).”A smart waste management with self-describing objects”. The Second International Conference on Smart Systems, Devices and Technologies (SMART'13).

Hong I, Park S, Lee B, Lee J, Jeong D, Park S.(2014).” IoT-based smart garbage system for efficient food waste management". The Scientific World Journal.

Jain, A.; Bagherwal, R.(2017). "Design and implementation of a smart solid waste monitoring and collection system". Proceedings of the Internet of Things 8th International Conference on Computing, Communication and Networking Technologies, Delhi, India.

Lundin AC, Ozkil AG, Schuldt-Jensen J. (2017). "Smart Cities: A Case Study in Waste Monitoring and Management". Proceedings of the 50th Hawaii International Conference on System Sciences.

Labib, S.M.(2017). "Volunteer GIS (VGIS) based waste management: A conceptual design and use of web 2.0 for smart waste management in Dhaka City". Proceedings of the Third International Conference on Research in Computational Intelligence and Communication Networks, West Bengal, India.

Mustafa, M.R.; Azir, K.N.F.(2017). "Smart Bin: Internet-of-Things Garbage Monitoring System”. MATEC Web Conf.

Muyunda, N.; Ibrahim, M.(2017). "Arduino-based smart garbage monitoring system: Analysis requirement and implementation". Proceedings of the International Conference on Computer and Drone Applications, Kuching, Sarawak, Malaysia.

Papalambrou A, Karadimas D, Gialelis J, Voyiatzis AG.(2015).” A versatile scalable smart waste-bin system based on resource-limited embedded devices". In Emerging Technologies \& Factory Automation (ETFA), IEEE.

Pardini, K.; Rodrigues, J.J.P.C.; Hassan, S.A.; Kumar, N.; Furtado, V. (2018). "Smart Waste Bin: A New Approach for Waste Management in Large Urban Centers". 3rd International Workshop of Communication for Networked Smart Cities. Proceedings of the IEEE $\left(88^{\text {th }}\right)$. Vehicular Technology Conference, Chicago, IL, USA.

Saha, H.N.; Auddy, S.; Pal, S.; Kumar, S.; Pandey, S.; Singh, R.; Singh, A.K.; Banerjee, S.; Ghosh, D.; Saha, S. (2017)."Waste management using Internet of Things (IoT)". Proceedings of the Annual Industrial Automation and Electromechanical Engineering Conference.$\left(8^{\text {th }}\right)$. Bangkok, Thailand.

Sharma N, Singha N, Dutta T. (2015)."Smart Bin Implementation for Smart Cities. International Journal of Scientific \& Engineering Research.

Shyam, G.K.; Manvi, S.S.; Bharti, P. (2017). "Smart waste management using Internet-of-Things (IoT)". Proceedings of the second International Conference on Computing and Communications Technologies, Kaushambi, India. 